\title{
Management of Treated Wastewater and Flood Water Using GIS for Environmental Protection in Jordan
}

\section{-Shueib and Kafrain Catchments}

\author{
Ghaida Abdallat1 ${ }^{*}$, Enas Harahshah ${ }^{2}$, Elias Salameh1 \\ ${ }^{1}$ National Center for Research and Development (NCRD), Amman, Jordan \\ ${ }^{2}$ Royal Jordanian Geographic Centre, Amman, Jordan \\ Email: ^ghidaaabdallat@yahoo.com
}

How to cite this paper: Abdallat, G. Harahshah, E., \& Salameh, E. (2020). Management of Treated Wastewater and Flood Water Using GIS for Environmental Protection in Jordan. Journal of Geoscience and Environment Protection, 8, 86-100. https://doi.org/10.4236/gep.2020.81006

Received: November 27, 2019

Accepted: January 13, 2020

Published: January 16, 2020

Copyright $\odot 2020$ by author(s) and Scientific Research Publishing Inc. This work is licensed under the Creative Commons Attribution International License (CC BY 4.0).

http://creativecommons.org/licenses/by/4.0/

\begin{abstract}
Management of various water resources has become a pivotal need for all catchments in Jordan. Storing treated wastewater applied in reservoirs that originally constructed to store flood and base flow water in the country. This practice has proved detrimental to the originally good quality reservoir waters, leading to additional water quality deterioration such as eutrophication issue, hence, separating treated wastewater from flood and base flow waters to guarantee the availability of better quality waters for higher quality uses such as drinking or recreation. This study focuses on the dams constructed in Kafrain and Shueib catchments, lying west and northwest of Amman. The results of hydrological, hydrogeological, geological, water quality and terrain measurements via Remote Sensing, Geographical Information System (GIS) and Digital Elevation Models (DEM) show that there are nine potential dam sites in the study area to construct. In Shueib catchment, two proposed dam sites were selected as suitable dams for fresh water harvesting and groundwater artificial recharge. While, two suggested dam sites are located downstream of Al-Salt and Fuhais wastewater treatment plants (WWTPs) for treated wastewater collection. In Kafrain catchment, three proposed dam sites were selected as suitable dams for fresh water harvesting and groundwater artificial recharge. Whereas, two suggested dam sites are located downstream of Wadi Sir WWTP, hereby, it can be used to collect the treated wastewater. The study is expected to serve as an example for other catchments in Jordan and elsewhere, especially in water scarcity areas where treated wastewater is stored together with flood and base flow waters.
\end{abstract}




\section{Keywords}

Treated Wastewater, Flood Flow, Base Flow, Storage, Jordan

\section{Background}

During the last decades, Jordan has started a new approach to water resource management, focusing on infrastructure, rehabilitating and improving water supply systems, and building and renovating several water networks and wastewater treatment plants (WWTPs). However, the scarcity of water resources and the increasing demands, especially for drinking, has increased the pressure to find sustainable solutions to conserve Jordan's water resources (Salameh et al., 2018). Thus, the Ministry of Water and Irrigation (MWI) in Jordan is working a lot for additional water resources for efficient management of water recourses (El-Naser, 1999). The majority of water resources consist of surface and groundwater and treated wastewater being used for irrigation mainly in the Jordan Valley (Mohsen, 2007).

The water requirements in Jordan for all relevant use applications are about $1400 \mathrm{MCM} / \mathrm{yr}$ (MWI, 2015), therefore, harvesting water via dams started, as an option to increase the availability of water across the country, to cover different use purposes (livestock, drinking and groundwater recharge) (MWI, JVA, 2006).

Until 2018, 28 dams have been constructed alongside wadis (MWI, open files); eight dams constructed in the north and middle parts of the Jordan Valley (JV) with several dams in the desert with a total capacity of 368 MCM (MWI, open files). Total dams capacity in Jordan is estimated at $350 \mathrm{MCM}$, including the desert dams (Hadadin, 2015). Moreover, many dams have been constructed in Jordan to collect flood water originating during the wet season of the year and base flows of wadis for the different use sectors during the dry summer months.

Afterwards, sewerage systems and wastewater treatment plants were constructed in the upstream areas of some existing dams, and the effluents of treatment allowed joining the waters in dams' reservoirs, which caused deterioration of dams' water qualities and rendered them unsuitable for uses requiring higher water qualities such as municipal supply and use in recreation purposes, such dams are King Talal (Gedeon, 1991, Al-Taani et al., 2018), Kafrain (Jasem, 2009), Shueib (Becker et al., 2001, Burjaq et al., 2017), partly wadi Arab (Ghrefat and Yusuf, 2006) and Kufranja (Al-Kharabsheh, 1999).

"It is not the water quantity, but its worsening quality that will bring us to our knees" (Salameh, 1996). It has become of utmost importance to make the best uses of the existing water resources in the country. Hereby, it is time to re-think about polluted water and treated wastewater, which are discharged into wadis and collected in the existing dams. Flood and base flow waters in Jordan can be used as a source of drinking water with some treatment such as filtration and chlorination. Whereas, the mixture of flood and base flow waters with treated 
wastewatercan only be used for restricted irrigation. Arepresentative example for the benefit of separation can be shown by rehabilitation of the Arab Dam (MWI, open files). That treated wastewater from the Irbid city and surrounding areas was stored in the Arab Dam. However, it is currently used for drinking purposes after separating and diverting treated wastewater into Jordan River (JR) diverted through a closed pipe.

Therefore, this study shows sustainable and practical solutions to increase the availability of fresh water resources in Shueib and Kafrain catchment areas. Through building new dams and/or wires to separate flood and base flow waters from treated effluents, which can save fresh flood and base flow waters from deterioration for higher quality water usesin the country (Al-Ansari \& Salameh, 2006). Thus, the potential of separating fresh flood and base flow water from treated effluents by constructing new reservoirs are discussed and evaluated in two catchment areas. This will guarantee additional water for higher quality water to be stored separated from the treated wastewater. Such water separation has also positive impacts on groundwater qualities and quantities. None the less, mixing of both waters remains a choice after separating them and can be done when need arises.

\section{Study Area}

The study area lies west and northwest of Amman. It is drained by two wadis; Shueib and Kafrain with their relatively small and simple catchment areas. Kafrain is located between the high lands in the east and the Jordan Valley in the west $\left(31^{\circ} 48^{\prime} 8^{\prime \prime} \mathrm{N}\right.$ and $\left.35^{\circ} 32^{\prime} 50^{\prime \prime} \mathrm{E}\right)$, with an approximate catchment area of 189 $\mathrm{km} 2$ with an annual rainfall of around 500 and $160 \mathrm{~mm} / \mathrm{yr}$ in the downstream area and in the west, respectively. The water of Kafrain dam is mainly used for irrigating downstream areas and for recharging the underlying aquifer (Salameh, 1996).

Shueib lies between $31^{\circ} 50^{\prime}$ to $32^{\circ} 02^{\prime} \mathrm{N}$ and $35^{\circ} 35^{\prime}$ to $35^{\circ} 50^{\prime} \mathrm{E}$, with an approximate catchment area of $178 \mathrm{~km}^{2}$ (Figure 1). Both wadis start in the eastern highlands of the Jordan Rift Valley at elevations about 1100 masl and extend to the southwest to the Jordan Valley to discharge into the Jordan River at elevations of around 381 (Shueib) and 400 (Kafrain) mbsl. The NE-SW extension of the wadis from the high mountains to where they enter the Jordan Valley area is around $20 \mathrm{~km}$.

Two dams were constructed at the entrance of both wadis into the Jordan River to collect flood and base flows (Kafrain with a capacity of 7.5 MCM and Shueib with 2.3 MCM (MWI, open files). The natural (pre-development) long term (30 years) discharge of Kafrain averaged 1.6 MCM/yr of flood and 4.8 $\mathrm{MCM} / \mathrm{yr}$ of base flows. Shueib discharged in average 3.9 MCM/yr of base flow and 1.8 MCM/yr of flood flows (MWI, open files).

Kafrain dam was constructed to collect flood and base flow waters during the rainy season, which gives a dynamic source of water for farmers in the area. 


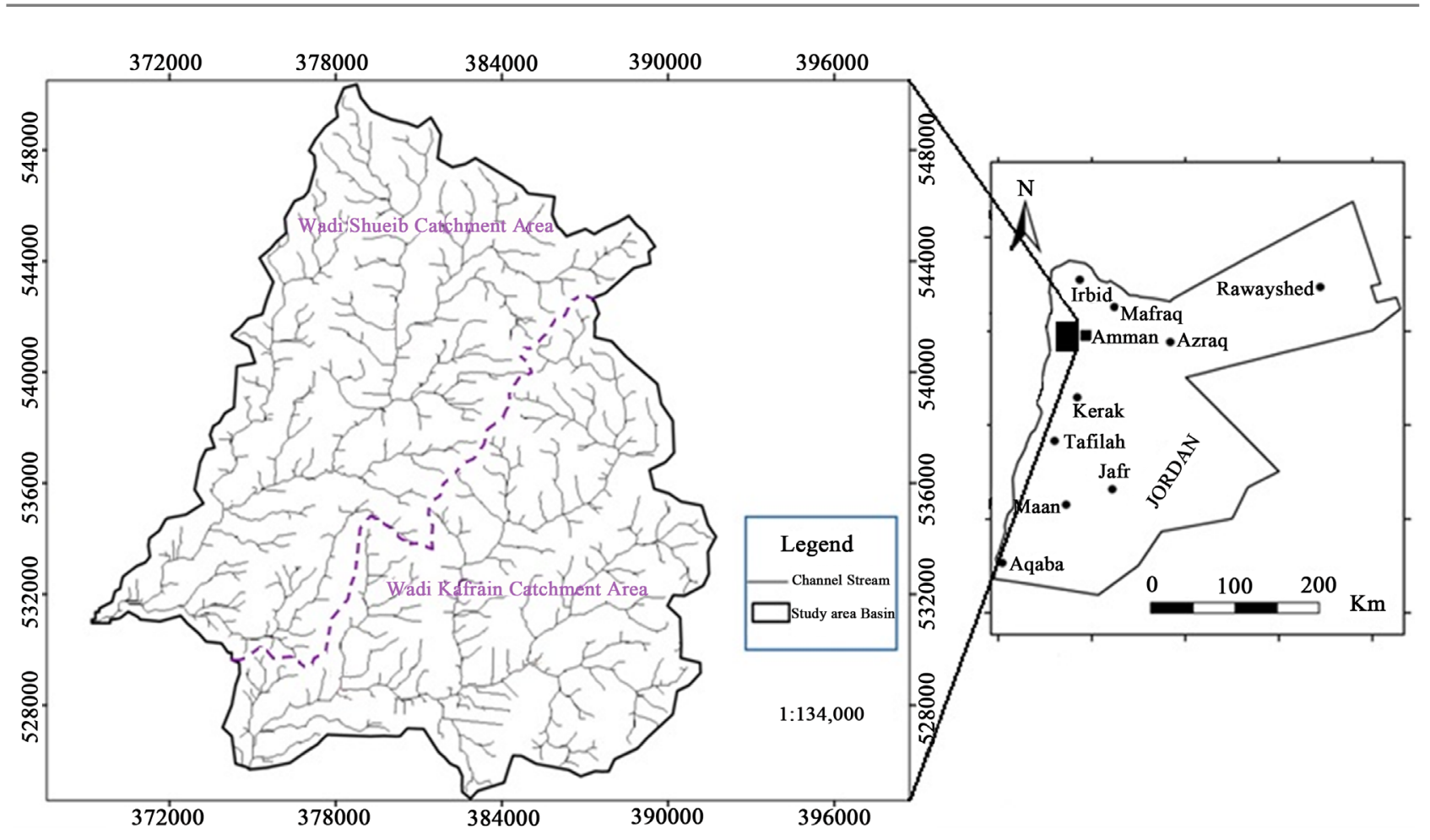

Figure 1. Location of the study area in Jordan; Shueib and Kafrain catchment areas.

However, the accelerated development within the catchment area especially urbanization (Na'ur and Wadi Sir Cities and Al-Hussein Medical City, the biggest medical center in the country) provides a huge amount of wastewater where it is treated in the centralized Wadi Sir wastewater treatment plant (WWTP). This plant lies upstream of Kafrain Dam and discharges its treated wastewater into the Wadi to join the waters collected in the dam. This has led to degradation of the Kafrain dam`s water quality; higher salt contents, eutrophication and bacterial growths.

The accelerated development in both catchment areas during the last four decades, especially urbanization, led to increasing municipal water use forcing the provision of sewerage systems and the construction of 3 wastewater treatment plants along both wadis, namely; Salt, Fuhais-Mahis and Wadi-Sir treatment plants. These three treatment plants were constructed upstream of Kafrain and Shueib dams and the treatment effluents allowed to join flood and base flow water of the wadis and its tributaries in the dams. This has led to degradation in the original water quality of the two dams causing higher salt contents, eutrophication and bacterial growths.

The final results of this mixing policy are:

- Deterioration of the good flood and base flow water quality, which used to collect in the dam reservoirs before allowing the treated wastewater to join these reservoirs.

- Eutrophication processes in these reservoirs' water leading to additional water quality deterioration and to anaerobic conditions in their bottom layers. 
- Flood and base flow waters have, in the water scarce country of Jordan, an added value because they can be used as a source of drinking water with minor treatment (e.g. filtration chlorination) compared to the mixture of flood and base flow waters with treated waste water, which can only be used for, generally, restricted irrigation.

To summarize the collection of treated wastewater in fresh water reservoirs is scientifically a detriment to the availability of fresh water in a water scarce country like Jordan.

\subsection{Climate}

The climate in the study areas is semi-arid in the highlands with an average precipitation of $450-500 \mathrm{~mm} / \mathrm{yr}$ to arid in the Jordan Valley area with $100-120$ $\mathrm{mm} / \mathrm{yr}$. The average long-term rainfall over the study area is $387 \mathrm{~mm} / \mathrm{yr}$ (NWMP, 1977 and MWI, open files). Figure 2 shows the rainfall distribution over the study area. However, Salameh (2016) reported that the averages precipitation in the study area has started decreasing in the last 25 years.

The average annual temperature in the highlands is around $20^{\circ} \mathrm{C}$ and in the Jordan Valley around $28^{\circ} \mathrm{C}$. The relative humidity ranges from $25 \%$ during hot summer days to around $90 \%$ on rainy days. Evaporation rates range from 2400 $\mathrm{mm} / \mathrm{yr}$ in the eastern mountainous parts to around $2300 \mathrm{~mm} / \mathrm{yr}$ in the western parts of the catchment areas in the Jordan Valley (DOM, Open files).

\subsection{Topography}

The area varies in elevation between 1100 masl (above sea level) in the highlands to 180 and $130 \mathrm{mbsl}$ (below sea level) at the entrance of wadi Shueib and Kafrain into the Jordan Valley area respectively. The average wadi slope is $6.1 \%$ reflected

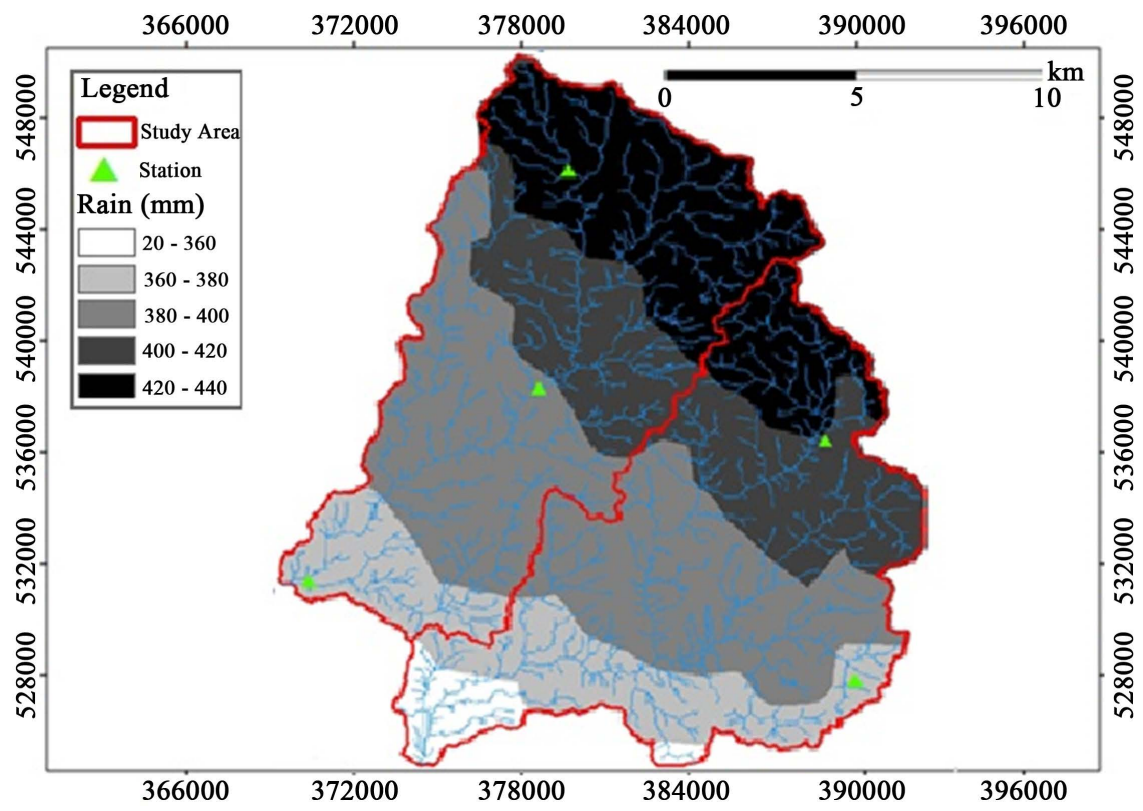

Figure 2. Rainfall distribution over the study area. 
in flood water velocities of up to $5 \mathrm{~m} / \mathrm{s}$, and very high rock erosion and transportation capabilities (Salameh et al., 2019).

\subsection{Hydrology}

The discharge of the two wadis consists of flood flows resulting from precipitation over the catchment areas in addition to base flows resulting from spring discharges. The two catchment areas of wadis Kafrain and Shueib function as discharge sites of the groundwater recharged (Salameh et al., 2019), within their catchment areas and in areas extending further east in the flat plateau areas of east Jordan. Along the wadis and side wadis of Kafrain and Shueib numerous fresh water springs issue from Upper Cretaceous calcareous rocks and small springs and seepages of generally brackish water issue from Lower Cretaceous and Triassic clastic rocks and join the flow of wadis. Because the study area is a discharge site for groundwater, it cannot be easily used for groundwater recharge (Salameh et al., 2019). But, water storage in dams with limited bank infiltration storage is quite possible with due consideration to the geology of proposed dam sites.

\subsection{Geology}

The main rocks building the area are calcareous Upper Cretaceous rocks composed of limestone, chert, phosphatic chert, marls and chalks. Along the lower reaches of the two wadis Shueib and Kafrain Lower Cretaceous sandstones crop out (Quennell, 1951). Very limited outcrops of Triassic silts and limestone are also encountered at the entrance of both wadis into the Jordan Valley area (Weltzel \& Morton, 1959, Bender 1974, NRA, open files).

Of interest for the present study are the Upper Cretaceous rocks of about $600 \mathrm{~m}$ in thickness composed of limestone, phosphaticchert, chert, marlstone and chalk building alternations of aquifers and aquicludes (Bandel \& Salameh, 2013).

Generally, the dip of the geological units is towards east as a result of the uplift of the Jordan Rift Valley eastern shoulders relative to the areas lying further east (plateau). But locally, the rocks can be tilted and dip in other directions, especially to the west as a result of down-faulting along N-S trending normal faults associated with the formation of the Rift Valley (Wiesemann \& Rosch, 1969).

\section{Methodology}

\subsection{Remote Sensing and GIS in Dam Site Selection}

Application of remote sensing and GIS techniques in hydrology is one of the most effective approaches, which provides a huge amount of valuable data in spatial and temporal resolutions. These techniques are used to assess the suitability of sites for the installation of small dams for the purpose of water harvesting in arid areas. The selection criteria are defined both in a qualitative and quantitative way. Qualitative criteria imply the identification of suitable valleys, 
wadi and physical characteristics based on satellite images interpretation, mainly DEM and large-scale available cartography. In this study, several remote sensing imageries were used to indentify dam sites, and used slope, aspect, land use, soil type, DEM and geological region to select the sites. In addition, these investigated parameters assessed on sites by geological surveys.

Moreover, the study area has been analyzed for locating suitable sites for the construction of new dams and weirs (henceforth dams) from the following points of view:

- The dam's locations have been selected based on land-use and land-cover maps, geomorphology of the basin, contour map and 3D surface view, drainage networks, and catchment area of dams.

- Topographic: volume and surface area of reservoir and size of dam using Remote Sensing and GIS. Furthermore, using different software (Erdas 9.1, Arc GIS 9.3, Global Mapper 11 and Surfer 9) in order to describe derivation of multi thematic layers to characterize the catchment areas.

- Hydrological: precipitation, potentials of flood and base flow discharges using existing data and climatic and hydrological methods.

- Initial hydrologic and geologic evaluation for water storage sites using common hydrologic and geologic methods.

- Evaluation of advantages of separate storage of treated waste water and flood and base flow waters to the water quality of stored water and its potential uses.

\subsection{Runoff Coefficient}

The National Water Master Plan (NWMP, 1977) calculated the flood runoff/ precipitation ratios for normal, wet and dry years in the study area for wadis Shueib and Kafrain (as given in Table 1, and Figure 3).

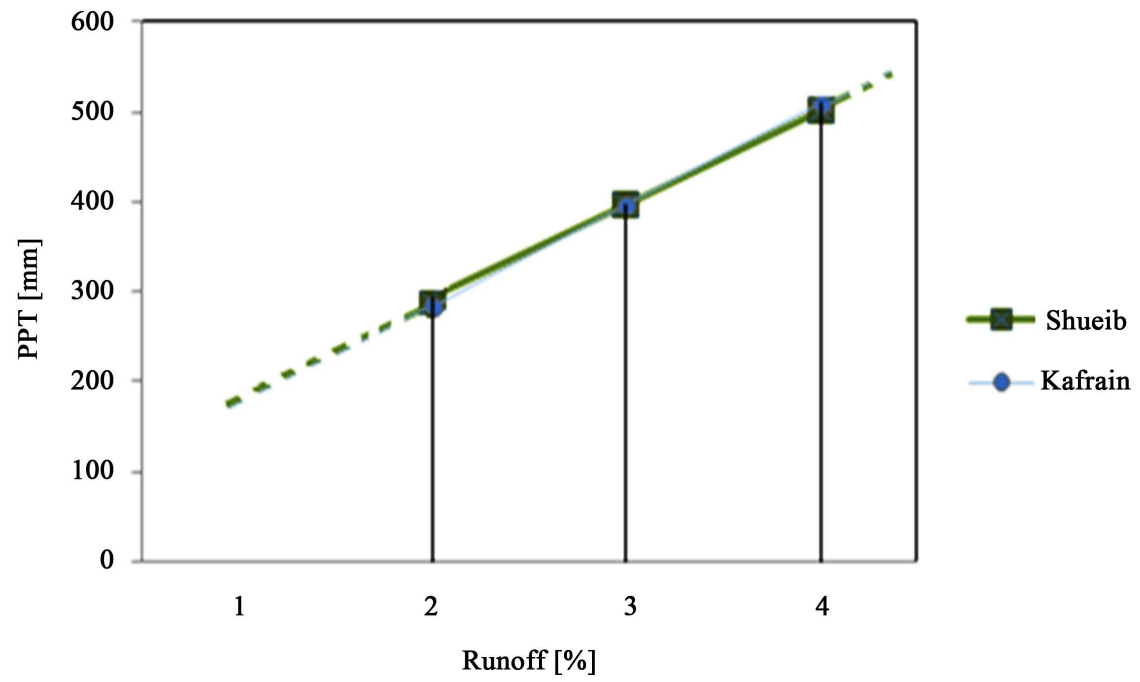

Figure 3. Precipitation, flood flows and runoff coefficients " $n$ " correlations for Kafrain and Shueib catchment areas based on the NWMP (1977) and other studies. 
Table 1. Natural average annual discharges of wadis Kafrain and Shueib during the pre-developmental era of their catchments (16 years of measurements, NWMP, 1977).

\begin{tabular}{rcc}
\hline Wadi & Flood flow $[\mathrm{MCM} / \mathrm{yr}]$ & Base flow $[\mathrm{MCM} / \mathrm{yr}]$ \\
\hline Shueib & 1.8 & 3.9 \\
Kafrain & 1.6 & 4.8 \\
\hline
\end{tabular}

According to the Equation (1):

$$
n=\frac{R}{P}
$$

where: $n$ : runoff coefficient, $R$ : quantity of discharged water/area of catchment and $P$. average precipitation over the catchment area.

Alkhoury (2011) carried out a detailed study on the correlation of precipitation and flood flows for small sub-catchment $\left(\mathrm{few} \mathrm{km}^{2}\right)$ of wadi Kafrain and correlated flood generation with the geology, topography, and slope and rainfall intensity. The study is very useful for detailed considerations of micro catchments with a single geologic formation cover (Table 2).

\section{Results and Discussion}

\subsection{Water Quality}

The qualities of flood and base flows which used to collect in Shueib and Kafrain dams before the diversion of treated wastewater (TWW) into them are given in Table 3. But the quality of the mixture of flood and base flow waters with the treated wastewater (dam's water) differs widely throughout the year in accordance with the mixing rations.

Dams' water composition becomes diluted in spring time due to a high percentage of floodwater joining the reservoirs compared to higher percentage of TWW inflows at the end of the dry season. Table 4 shows the composition of dams' water during the dry season. By comparing both Table 3 and Table 4, the negative impacts of the treated wastewater on the dam's water composition become clear $\left(\mathrm{BOD}_{5}, \mathrm{COD}, \mathrm{NO}_{3}, \mathrm{PO}_{4}\right.$ etc.).

In order to keep the percentage of evaporation below $12 \%$ of the water amount collected in the potential dams, dams' height of $20 \mathrm{~m}$ was considered, knowing that evaporation rates within the two catchments range from 2300 $2400 \mathrm{~mm} / \mathrm{yr}$. By higher percentages of evaporation from dam reservoirs, reservoirs water salinities can reach concentrations beyond water use requirement; for instance, the EC values of treated effluents are around $1200 \mu \mathrm{S} / \mathrm{cm}$ when $12 \%$ of the water evaporates the rest water EC value will be $1360 \mu \mathrm{S} / \mathrm{cm}$. Knowing that agriculture in the Jordan Valley requires water salinities of less than 1500 $\mu \mathrm{S} / \mathrm{cm}$ and knowing that along the flow paths from potential dam sites to use sites in the Jordan Valley area further evaporation takes place therefore, a margin of security of $140 \mu \mathrm{S} / \mathrm{cm}(1500-1360 \mu \mathrm{S} / \mathrm{cm})$ is left to account for that.

As discussed above flood and base flow waters in the area have low salinities and low pollution parameters concentrations (such as $\mathrm{NO}_{3}, \mathrm{PO}_{4}, \mathrm{COD}, \mathrm{BOD}_{5}$ ) 
Table 2. Runoff coefficients " $n$ " of wadis Shueib and Kafrain for dry, normal and wet years (Natural conditions during the pre-developmental era of their catchments (NWMP, 1977)).

\begin{tabular}{|c|c|c|c|c|c|c|c|}
\hline \multirow{2}{*}{ Wadi } & \multirow{2}{*}{ Type of year } & \multicolumn{2}{|c|}{ Areal Rainfall } & \multirow{2}{*}{$\begin{array}{l}\text { Runoff coefficients } \\
\text { "n" }\end{array}$} & Flood flow & Base flow & Total \\
\hline & & $\mathrm{mm} / \mathrm{yr}$ & $\mathrm{MCM} / \mathrm{yr}$ & & \multicolumn{3}{|c|}{$\mathrm{MCM} / \mathrm{yr}$} \\
\hline \multirow{3}{*}{ Shueib } & Dry & 294 & 52.3 & 0.8 & 0.42 & 5.6 & 6.0 \\
\hline & Average & 398 & 70.8 & 2.5 & 1.77 & 8.0 & 9.77 \\
\hline & Wet & 502 & 89.4 & 4.6 & 4.11 & 10.4 & 14.5 \\
\hline \multirow{3}{*}{ Kafrain } & Dry & 284 & 53.7 & 0.2 & 0.11 & 8.4 & 8.5 \\
\hline & Average & 397 & 75.0 & 1.8 & 1.35 & 12.0 & 13.35 \\
\hline & Wet & 510 & 96.4 & 3.6 & 3.47 & 15.6 & 19.07 \\
\hline
\end{tabular}

Table 3. Composition of flood and inlet water of both wadis Shueib and Kafrain before allowing the treated wastewater to join the dams and the composition of the mixtures of base flows and treated wastewater during summer months $(\mathrm{EC}$ in $\mu \mathrm{S} / \mathrm{cm}, \mathrm{PO} 4, \mathrm{COD}$ and BOD in $\mathrm{mg} / \mathrm{l}$, all others in meq/l), (MWI, open files).

\begin{tabular}{|c|c|c|c|c|c|c|c|c|c|c|c|c|c|c|c|}
\hline Site/ & Parameter & EC & $\mathrm{pH}$ & $\mathrm{T}$ & $\mathrm{Ca}$ & $\mathrm{Mg}$ & $\mathrm{Na}$ & $\mathrm{K}$ & $\mathrm{Cl}$ & $\mathrm{HCO}_{3}$ & $\mathrm{SO}_{4}$ & $\mathrm{NO}_{3}$ & $\mathrm{PO}_{4}$ & COD & $\mathrm{BOD}_{5}$ \\
\hline \multirow{4}{*}{ Shueib } & \multirow{2}{*}{ Inlet } & 635 & 8.4 & 20 & 3.5 & 1.6 & 1.24 & 0.16 & 1.45 & 3.34 & 1.5 & 0.55 & 0.57 & 0.50 & 0.1 \\
\hline & & 640 & 8.5 & 16 & 3.5 & 1.6 & 0.77 & 0.11 & 1.4 & 3.55 & 0.66 & 0.64 & 0.12 & 0.72 & 0.2 \\
\hline & Flood Flow & 160 & 8.4 & 7.0 & 1.6 & 0.2 & 0.29 & 0.08 & 0.25 & 1.42 & 0.41 & 0.08 & 0.7 & 0.65 & 0.01 \\
\hline & Mixture $^{\star}$ & 970 & 8.3 & 23 & 3.4 & 3.3 & 8.52 & 2.46 & 3.82 & 3.72 & 2.4 & 0.61 & 2.16 & 12.5 & 1.6 \\
\hline \multirow{4}{*}{ Kafrain } & \multirow{2}{*}{ Inlet } & 705 & 8.2 & 14 & 3.4 & 1.9 & 1.9 & 0.16 & 2.00 & 3.09 & 1.5 & 0.42 & 0.68 & 0.6 & 0.3 \\
\hline & & 603 & 8.2 & 20 & 3.6 & 2.7 & 1.7 & 0.09 & 2.45 & 2.91 & 1.5 & 0.45 & 0.52 & 0.52 & 0.15 \\
\hline & Flood Flow & 136 & 8.9 & 7.5 & 1.5 & 0.2 & 029 & 0.07 & 0.4 & 1.18 & 0.35 & 0.09 & 0.7 & 0.0 & 0.0 \\
\hline & Mixture* & 1080 & 7.8 & 26 & 4.0 & 1.6 & 5.9 & 021 & 4.11 & 4.89 & 2.4 & 0.5 & 2.2 & 10.3 & 2.2 \\
\hline
\end{tabular}

${ }^{*}$ Mixture of base flow water and treated wastewater during the dry summer months at the inlet of dams.

Table 4. Electric conductivity, $\mathrm{pH}$ and pollution parameters in the effluents of Al-Salt, Fuheis/Mahis and Kafrain wastewater treatment plants (MWI, open files).

\begin{tabular}{ccccccc}
\hline Site/parameter & $\begin{array}{c}\mathrm{EC} \\
{[\mu \mathrm{S} / \mathrm{cm}]}\end{array}$ & $\mathrm{pH}$ & $\begin{array}{c}\mathrm{NO}_{3} \\
{[\mathrm{mg} / \mathrm{l}]}\end{array}$ & $\begin{array}{c}\mathrm{PO}_{4} \\
{[\mathrm{mg} / \mathrm{l}]}\end{array}$ & $\begin{array}{c}\mathrm{COD}^{2} \\
{[\mathrm{mg} / \mathrm{l}]}\end{array}$ & $\begin{array}{c}\mathrm{BOD}_{5} \\
{[\mathrm{mg} / \mathrm{l}]}\end{array}$ \\
\hline Salt (Shueib) & 1324 & 7.44 & 2.50 & 10.57 & 86 & 45 \\
Fuheis/Mahis (Shueib) & 1358 & 7.36 & 6.11 & 12.5 & 130 & 39 \\
Wadi Sir (Kafrain) & 1250 & 7.52 & 1.02 & 13.57 & 142 & 61 \\
\hline
\end{tabular}

and agrochemicals, which are not to be expected in any concentrations of concern because of the catchments as dry farming land and very limited irrigation along wadi sides as reported by Jiménez and Asano (2008) and (GTZ, 1977). In addition, Zimmo and Imseih (2010) have highlighted a list of conclusions and recommendations deemed necessary to improve wastewater management and reuse in the Wastewater management and reuse in the Eastern Mediterranean Region (Bahrain, Egypt, Islamic Republic of Iran, Jordan, Kuwait, Lebanon, Morocco, Saudi Arabia, Sudan, Syrian Arab Republic and Tunisia). 


\subsection{Sites Selections}

After studying the geological, hydrological and environmental conditions and factors such as capacities and surface areas of suggested dam reservoirs nine proposed locations of dams have been selected. Four dams are located within Shueib catchment and five dams within Kafrain catchment (Figure 4). Moreover,

Table 5. Approximated areas and capacities of suggested dam sites (Height of dam $20 \mathrm{~m}$ and maximum water level $18 \mathrm{~m}$ ).

\begin{tabular}{cccc}
\hline Catchment & Site No. & $\begin{array}{c}\text { Volume of stored } \\
\text { water }\left(\mathrm{Mm}^{3}\right)\end{array}$ & $\begin{array}{c}\text { Surface area of filled } \\
\text { reservoirs }\left(1000 \mathrm{~m}^{2}\right)\end{array}$ \\
\hline \multirow{3}{*}{ Shueib } & 1 & 0.483 & 80 \\
& 2 & 0.198 & 33 \\
& 3 & 0.360 & 60 \\
Kafrain & 4 & 0.108 & 18 \\
& 5 & 0.32 & 44 \\
& 7 & 0.31 & 30 \\
& 8 & 0.40 & 47 \\
& 9 & 0.51 & 58 \\
\hline
\end{tabular}

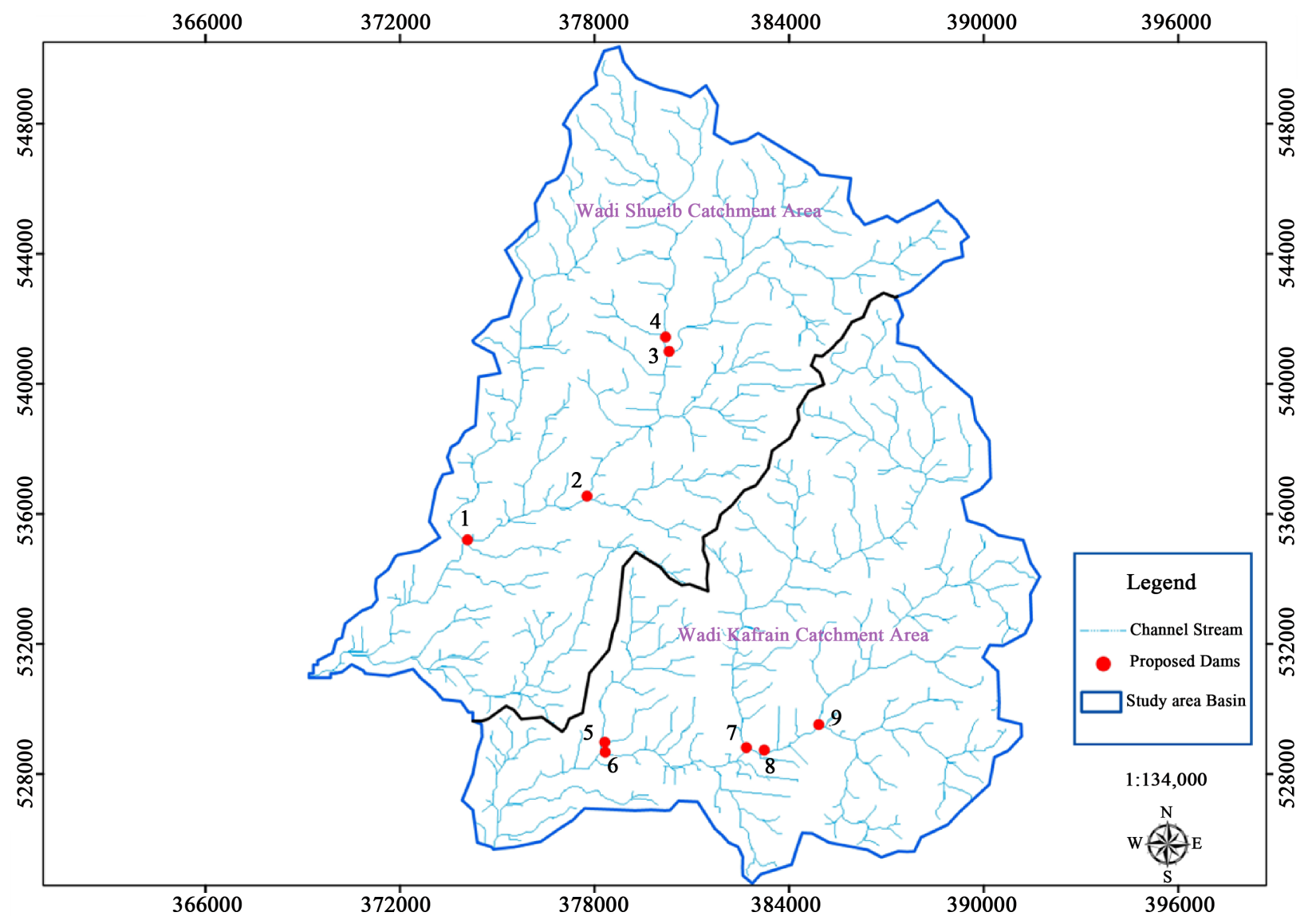

Figure 4. Nine proposed dam sites in both wadi Shueib and Kafrain catchment areas. 
selection of dam sites and types depends on many factors such as type and amount of water to be collected, topography, geology, climate, potential use of the harvested water, and present land use. The topography is used to calculate size of dams and capacities and surface areas of their reservoirs, the geology is used to ensure low leakages and adequate reservoir water quality, the climate is used to insure low evaporation from reservoir lakes and land use is used in order to avoid damage to existing land uses.

From a geological point of view the area is covered by calcareous rocks and sandstones forming huge blocks (Kms in length and width) in which form N-S step faults towards the Jordan Valley. No obvious recent activities can be observed on these faults, especially not in the suggested dam sites given in Figure 4. From a hydrogeological point of view groundwater in the study area is effluent with numerous springs and seepages. Hence, the water collected in the dams will not recharge the aquifers but may infiltrate from dams' lakes and build dam abutment storage. Even if some infiltrating water joins the groundwater it will certainly discharge again through dams' neighboring springs and seepages. From a hydrological point of view the catchment areas of each dam can provide the flood and base flow amounts to fill the suggested dams. From an engineering geological point of view the wadis where dams can be constructed have cut into limestones, dolomites, marly limestones, sandstones and wadi bottoms are covered by thin veneers of gravel. Therefore, construction of concrete and landfill dams is not complicated by unstable or weak geological set-up.

In Shueib catchment (Figure 5), proposed dam sites (number one and two) were selected as suitable dams for fresh water harvesting and groundwater artificial recharge. While, suggested dam sites (number three and four) are located downstream of Al-Salt and Fuhais wastewater treatment plants for treated wastewater collection.

In Kafrain catchment, as shown in Figure 6, three proposed dam sites were selected as suitable dams for fresh water harvesting and groundwater artificial recharge. Whereas, two suggested dam sites are located downstream of Wadi Sir WWTP, hereby, it can be used to collect the treated wastewater.

\section{Conclusion}

The current study tries to repair some of the damage inflicted on the good quality water of flood and base flows by adding treated wastewater to flood and base flows. It seems that the optimal option to alleviate further damage of this action is by storing them separately. To achieve that purpose new dam sites have to be found within the studied catchments of wadi Shueib and Kafrain. The results of hydrological, hydrogeological, geological, water quality and terrain measurements using remote sensing, geographic information system and digital elevation models show that there are within the two catchment areas potential sites to construct new dams in order to separate flood and base flow waters afar from treated wastewater. This separation will guarantee additional high quality water for uses in drinking and recreational purposes. 


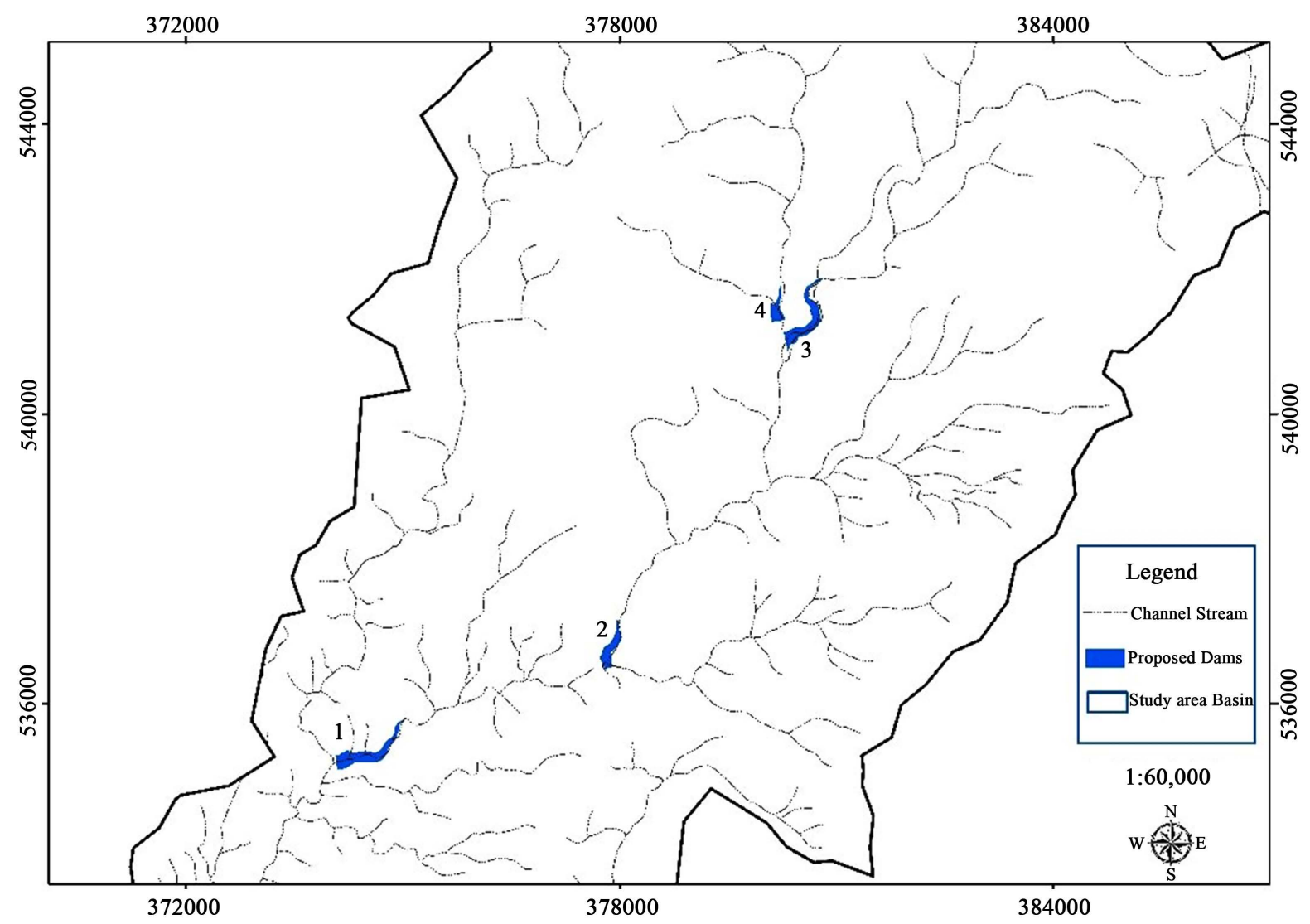

Figure 5. Suggested new dam sites in wadi Shueib catchment area.

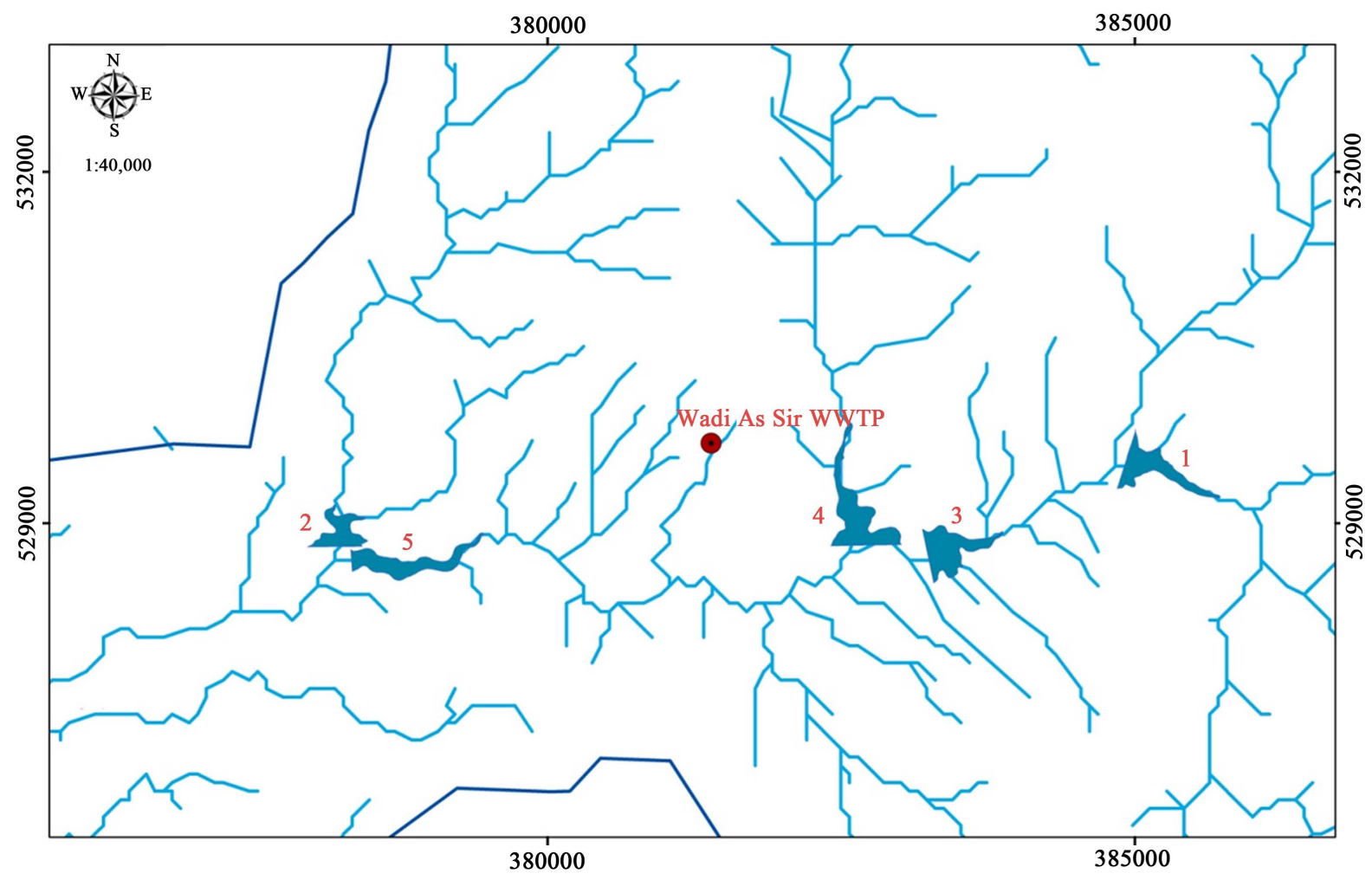

Figure 6. Suggested new dam sites in wadi Kafrain catchment area. 
Although the amounts of water to be collected in the suggested fresh water dams are small, of less than one million cubic meters per dam, these amounts in the water stressed country of Jordan are very important and can solve many local water supply problems.

After developing all surface and groundwater resources to their utmost extent, Jordan can still implement some managerial measures on the supply and demand sides to add some water to the use sectors. One of these measures is dealt with in this paper and incorporates separating the storage of good quality water afar from impaired one.

The results of this study are expected to encourage to carry out similar studies on larger catchments of thousands of $\mathrm{km}^{2}$ where treated wastewater has been added to the good quality flood and base flows of wadis and rivers and dams constructed on them such as King Talal Dam in Zarqa River catchment.

\section{Acknowledgements}

This work was supported by the USAID-USGS project "Acceleration of Aquifer Storage and Recovery in the MENA Region" [grant numbers GI7AS00001].

\section{Conflicts of Interest}

The authors declare no conflicts of interest regarding the publication of this paper.

\section{References}

(1977). NWMP: National Water Master Plan of Jordan. Eschborn: Natural Resources Authority (NRA), Jordan and German Technical Cooperation Agency (GTZ).

Agrar und Hydrotechnik and GTZ (1977) National Water Master Plan of Jordan. 8 Volumes, Essen, Hannover.

Al-Ansari, N. A., \& Salameh, E. (2006). Jordan Country Study. In Efficient Management of Wastewater, Its Treatment and Reuse in Four Mediterranean Countries (pp. 14-73). Ashwa Amman: Alshaeb Press.

Al-Kharabsheh, A. A. (1999). Influence of Urbanization on Water Quality at Wadi Kufranja Basin (Jordan). Journal of Arid Environments, 43, 79-89. https://doi.org/10.1006/jare.1999.0534

Alkhoury, W. (2011). Hydrological Modelling in the Meso Scale Semiarid Region of Wadi Kafrein, Jordan-The Use of Innovative Techniques under Data Scarcity. Doctoral Dissertation, Göttingen: NiedersächsischeStaats-und Universitätsbibliothek Göttingen.

Al-Taani, A. A., El-Radaideh, N. M., \& Al Khateeb, W. M. (2018). Status of Water Quality in King Talal Reservoir Dam, Jordan. Water Resources, 45, 603-614.

https://doi.org/10.1134/S0097807818040048

Bandel, K., \& Salameh, E. (2013). Geologic Development of Jordan-Evolution of Its Rocks and Life.

Becker, K., Ali, W., \& Hoetzl, H. (2001). Study on Water Quality in the Area of Wadi Shueib (p. 10). Jordan Valley: WIR.

Bender, F. (1974). Geology of Jordan-Contributions to the Regional Geology of the Earth. Stuttgart: GebruderBorntraeger Berlin. 
Burjaq, S. Z., Abu-Romman, S. M., \& Haddad, M. A. (2017). Molecular Characterization of Virulence Genes and Antibiotic Resistance among Fecal Escherichia coli Isolated from Surface Water of Wadi Shueib Jordan. The International Arabic Journal of Antimicrobial Agents, 7, 4. https://doi.org/10.3823/804

Department of Metrology (DOM). Open Files, Jordan.

El-Naser, H. (1999). Water Resources Management Policy Reforms for Jordan, Country Case Study. In Proceedings of the 2nd Regional on Policy Reform in Water Resources Management, Middle East, N. Africa, Mediterranean Water Initiative (pp. 105-116). Washington DC: The World Bank.

Gedeon, R. (1991). The Potential Impact of Industrial Wastes on Water Resources in Amman-Zarka Basin. In Water Pollution in Jordan: Causes and Effects. Proceedings of the Second Environmental Pollution Symposium (pp. 51-72). Amman (Jordan): Friedrich Ebert Stiftung.

Ghrefat, H., \& Yusuf, N. (2006). Assessing Mn, Fe, Cu, Zn, and Cd Pollution in Bottom Sediments of Wadi Al-Arab Dam, Jordan. Chemosphere, 65, 2114-2121. https://doi.org/10.1016/j.chemosphere.2006.06.043

Hadadin, N. (2015). Dams in Jordan Current and Future Perspective. Canadian Journal of Pure and Applied Sciences, 9, 3279-3290.

Jasem, H. (2009). Groundwater Vulnerability in wadi Kafrain catchment and Its Surrounding Areas Using GIS, Ground-Truthing and Lab Analysis. Doctoral Dissertation, Amman: University of Jordan.

Jiménez, B., \& Asano, T. (2008). Water Reuse: An International Survey of Current Practice, Issues and Needs. London: IWA.

Ministry of Water and Irrigation (MWI) and Jordan Valley Authority (JVA) (2006). Policy and Adaptation in the Jordan Valley, Rosenberg International Forum V Managing Upland Watersheds in an Era of Global Climate Change Banff, Canada.

Ministry of Water and Irrigation (MWI). Open Files, Jordan.

Mohsen, M. S. (2007). Water Strategies and Potential of Desalination in Jordan. Desalination, 203, 27-46. https://doi.org/10.1016/j.desal.2006.03.524

NRA: Natural Resources Authority. Mapping Program Salt Sheet (NRA Open Files).

Quennell, A. M. (1951). The Geology and Mineral Resources of (Former) Trans-Jordan. HM Stationery Office.

Salameh, E. (1996). Water Quality Degradation in Jordan: Impacts on Environment, Economy and Future Generations Resources Base. Friedrich-Ebert-Stiftung.

Salameh, E. (2016). Effects of Climatic Changes on Surface and Groundwater Resources in the Northwestern Part of Jordan. International Journal of Environmental and Agriculture Research, 2, 23-32.

Salameh, E., Abdallat, G., \& van der Valk, M. (2019). Planning Considerations of Managed Aquifer Recharge (MAR) Projects in Jordan. Water, 11, 182.

https://doi.org/10.3390/w11020182

Salameh, E., Shteiwi, M., \& Al Raggad, M. (2018). Water Resources of Jordan: Political, Social and Economic Implications of Scarce Water Resources (Vol. 1). Berlin: Springer. https://doi.org/10.1007/978-3-319-77748-1_1

Wetzel, R., \& Morton, D. M. (1959). Contribution a la geologie de la Transjordanie (pp. 95-191). Museum national d'histoirenaturelle.

Wiesemann, G., \& Rosch, H. (1969). Das Apatit Vorkommen von Suweilih bei Amman 
(Nord Jordanien). Geol. Jahrb., Beihefte, No. 81, 177-214.

Zimmo, O. R., \& Imseih, N. (2010). Overview of Wastewater Management Practices in the Mediterranean Region. In Waste Water Treatment and Reuse in the Mediterranean Region (pp. 155-181). Berlin, Heidelberg: Springer.

https://doi.org/10.1007/698 2010 63 